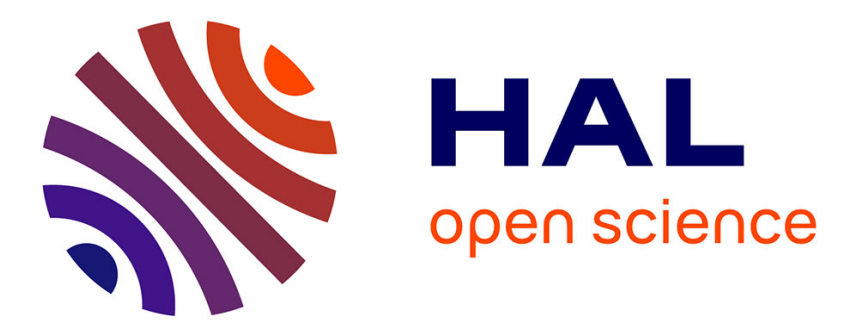

\title{
Plasma-Catalytic Dry Reforming of CH4 over Calcium Oxide: Catalyst Structural and Textural Modifications
}

\author{
Nassim Bouchoul, Elodie Fourre, Jean-Michel Tatibouet, Catherine
}

Batiot-Dupeyrat

\section{- To cite this version:}

Nassim Bouchoul, Elodie Fourre, Jean-Michel Tatibouet, Catherine Batiot-Dupeyrat. PlasmaCatalytic Dry Reforming of CH4 over Calcium Oxide: Catalyst Structural and Textural Modifications. Plasma Chemistry and Plasma Processing, 2019, 39 (3), pp.713-727. 10.1007/s11090-019-09966-9 . hal-02351936

\author{
HAL Id: hal-02351936 \\ https://hal.science/hal-02351936
}

Submitted on 1 Dec 2020

HAL is a multi-disciplinary open access archive for the deposit and dissemination of scientific research documents, whether they are published or not. The documents may come from teaching and research institutions in France or abroad, or from public or private research centers.
L'archive ouverte pluridisciplinaire HAL, est destinée au dépôt et à la diffusion de documents scientifiques de niveau recherche, publiés ou non, émanant des établissements d'enseignement et de recherche français ou étrangers, des laboratoires publics ou privés. 


\title{
Plasma-catalytic dry reforming of $\mathrm{CH}_{4}$ over calcium oxide: catalyst structural and textural modifications
}

\author{
Nassim Bouchoul, Elodie Fourré, Jean-Michel Tatibouët, Catherine Batiot-Dupeyrat* \\ IC2MP, ENSIP, Université de Poitiers - UMR CNRS 7285 \\ 1 rue Marcel Doré, TSA 41105, 86073 Poitiers cedex 9 (France) \\ *E-mail : catherine.batiot.dupeyrat@univ-poitiers.fr
}

\begin{abstract}
The coupling of catalyst and nonthermal plasma for the dry reforming of methane was investigated with a special attention to the textural and structural catalyst modifications under plasma discharge. The reaction was performed using calcium oxide as material located into the DBD plasma reactor, while the deposited power was fixed at $8 \mathrm{~W}$ and the total gas flow at 40 $\mathrm{mL} / \mathrm{min}$ (75\% helium as diluent). The results obtained showed that $\mathrm{CaO}$ grain size affects the reactant transformation in the range: $250-1000 \mu \mathrm{m} . \mathrm{CH}_{4}$ and $\mathrm{CO}_{2}$ conversion increases from 18.1 to $21.1 \%$ and 8.7 to $11.2 \%$ respectively from the biggest to the smallest catalyst grain. Ethane formation is favored when the biggest particles are used, corresponding to the largest gas space between grains, suggesting the preferential recombination of $\mathrm{CH}_{3}$ radicals to form $\mathrm{C}_{2} \mathrm{H}_{6}$ in gaseous phase and not at the surface of the solid. The reaction was performed from room temperature to $300^{\circ} \mathrm{C}$, little effect were observed for methane conversion while high $\mathrm{CO}_{2}$ conversion was observed during the 20 minutes at $300^{\circ} \mathrm{C}$. The characterization of the catalyst after reaction under plasma shows structural catalyst modification and the carbonation of $\mathrm{CaO}$ at the highest temperatures. The amount of carbonate species was quantified and the results show that 59 monolayers of $\mathrm{CaCO}_{3}$ are obtained after one hour of plasma at $\mathrm{P}=8 \mathrm{~W}$ using a mixture with a $\mathrm{CH}_{4} / \mathrm{CO}_{2}$ ratio of 2 .
\end{abstract}

Keyword: nonthermal plasma, methane, carbon dioxide, calcium oxide 


\section{Introduction}

Dry reforming of methane reaction has been the subject of many studies since in this process two significant greenhouse contributors are valorized, producing syngas with low $\mathrm{H}_{2} / \mathrm{CO}$ ratio suitable for the production of methanol and liquid hydrocarbons using Fischer-Tropsch processes [1,2]. The reaction is usually carried out at temperatures higher than $700^{\circ} \mathrm{C}$ due to thermodynamic limitations and by using catalysts based on noble metals, such as $(\mathrm{Rh}, \mathrm{Ru}, \mathrm{Pt}$, and Pd), known for their significant resistance to carbon coking [3]. Research efforts were performed on lower cost transition metals such as $(\mathrm{Ni}, \mathrm{Co}, \mathrm{Fe})$ that can overcome carbon deposition limitation [4]. However, despite the considerable progress made in this field, dry reforming of $\mathrm{CH}_{4}$ using conventional catalytic processes still faces two major drawbacks that limit commercial application: the high operating temperatures and the catalyst deactivation due to coke deposition at the surface of active catalytic species [5]. Nonthermal plasma is considered as an attractive alternative method for methane and carbon dioxide transformation [6]. Many reactions are initiated at low temperature under the plasma discharge leading to valuable chemicals such as hydrocarbons [7] or oxygenates [8]. However the selectivity towards targeted products is often difficult to achieve due to the occurrence of a large number of reactions in gaseous phase. The coupling of catalyst and plasma was proposed to overcome this drawback [9]. In many studies, the selected catalysts were similar to those used in conventional thermal catalytic processes, and the influence of $\mathrm{Ni} / \mathrm{Al}_{2} \mathrm{O}_{3}$ located into the plasma zone was investigated using different plasma reactor geometry. The presence of the reduced $\mathrm{Ni} / \mathrm{Al}_{2} \mathrm{O}_{3}$ in the discharge lead to a decrease in conversions of $\mathrm{CH}_{4}$ and $\mathrm{CO}_{2}$ [10]. It was proposed that the presence of conductive $\mathrm{Ni}$ active sites decreased the electric field strength and consequently the electron density reducing thus reactant conversion $[11,12]$. From these works it is possible to conclude that the combination of plasma and catalyst requires the development 
of specific materials able to transform reactants present under active species form, such as excited species, radicals and ions [13].

The combination of nonthermal plasma with different metal oxides was investigated, while alumina possesses no catalytic activity in the thermal dry reforming of methane reaction, a significant improvement in $\mathrm{CH}_{4}$ and $\mathrm{CO}_{2}$ conversion over $\mathrm{Al}_{2} \mathrm{O}_{3}$ was observed when coupled with plasma [14]. Gadzhieva [15] showed that $\mathrm{CH}_{4}$ adsorption sites were formed on the $\gamma-\mathrm{Al}_{2} \mathrm{O}_{3}$ surface by molecular and dissociative mechanisms under the action of an electric-discharge plasma at room temperature.

Spinel nickel ferrite nanoparticles $\mathrm{NiFe}_{2} \mathrm{O}_{4}$, embedded in silica was successfully used by Zheng et al. [16]. The authors exhibited excellent catalytic performance and high resistance to carbon formation during dry reforming under ambient conditions.

Jiang et al. [17] showed that $\mathrm{CH}_{4}$ and $\mathrm{CO}_{2}$ conversions are reduced with the use of a zeolite $\mathrm{A}$, but the formation of carbon black was inhibited. A higher $\mathrm{CO}_{2}$ conversion and a lower $\mathrm{CH}_{4}$ conversion was reported by Zhang et al. using $\mathrm{La}_{2} \mathrm{O}_{3} / \mathrm{Al}_{2} \mathrm{O}_{3}$ under pulse corona plasma [18].

There are needs to develop more deeply the coupling of plasma and catalysis and the main goal of the present study was to investigate particularly the structural and textural modifications of materials under plasma discharge.

In this respect, we decided to study the influence of the presence of calcium oxide located in a packed bed DBD reactor. This material was chosen due to its relatively low dielectric constant (9-30), since as shown by Wang et al. [19] a too high dielectric constant of the packing material limits the discharge to the contact point of the beads and consequently is not favorable to develop reactions at the surface of a catalyst. Moreover the basic properties of $\mathrm{CaO}$, was expected to favor $\mathrm{CO}_{2}$ adsorption and activation, since in thermal catalytic processes $\left(\mathrm{T}>700^{\circ} \mathrm{C}\right)$ it is known that carbonate species are involved in the reaction of dry reforming of methane. 


\section{Experimental part}

The reaction was performed at room temperature, $100,200,300^{\circ} \mathrm{C}$ and atmospheric pressure in a coaxial dielectric barrier discharges (DBD) reactor (figure 1). The nonthermal plasma reactor (dielectric barrier discharge) was composed of an alumina tube (ID: 4mm; OD: $6 \mathrm{~mm}$ ), a stainless steel electrode inside the reactor $(1.0 \mathrm{~mm})$ and a copper electrode wrapped around the alumina tube (100 $\mathrm{mm}$ long).

For plasma reactions performed at room temperature, an optic fiber was used to measure the temperature rise closed to the plasma zone. For that purpose, a fiber optic temperature sensor Optocon (TS2: $200 \mu \mathrm{m}$ of diameter) was introduced right below the plasma zone. It was checked that the temperature did not exceed $373 \mathrm{~K}$ under the experimental conditions used.

Helium, methane and carbon dioxide were flowed through the plasma reactor at a total flow rate of $40 \mathrm{~mL} . \mathrm{min}^{-1}$ using different ratio $\mathrm{CH}_{4} / \mathrm{CO}_{2}$ (from 0.5 to 2 ) with a constant concentration in He: $75 \%$, corresponding to a residence time of $1.8 \mathrm{~s}$ without catalyst and $1.6 \mathrm{~s}$ in the presence of a catalyst.

A sinusoidal supply of power was applied across the electrode (TG1010A Aim-TTi, Thurlby Thandar Instruments Brand). The discharge power, calculated through the figure of Lissajous (Fig. 2), was fixed at 8 watts, keeping the frequency constant at $800 \mathrm{~Hz}$ and varying the voltage from 12 to $14 \mathrm{kV}$. At room temperature the voltage was equal to $14 \mathrm{kV}$ and was decreased at $12 \mathrm{kV}$ when the reaction was performed at $300^{\circ} \mathrm{C}$. The electrical signals were monitored with high voltage probes (PMK, model PHV4-2757) connected to an oscilloscope (waveRunner 62 $\mathrm{Xi}$, Lecroy). The applied voltage and current intensity of the DBD at an operating frequency of $800 \mathrm{~Hz}$ are shown in Fig. 3.

The oxide used in this study are commercial products supplied by ACROS. The powder occupies all the plasma region, the solid was packed between two glass wool plug, the gas flow 
coming from the top of the reactor. The solids were characterized before and after plasma treatments.

Surface areas were measured according to the BET procedure. The nitrogen adsorptiondesorption isotherms were determined with a Micromeritics Flowsorb II 2300 appartus at $196^{\circ} \mathrm{C}$

Thermogravimetric analysis were performed with a SDTQ600TA analyser under a $100 \mathrm{~mL} / \mathrm{min}$ flow of air up to $1173 \mathrm{~K}$.

The catalysts were characterized by X-Ray Diffraction (XRD) using a Siemens D-5005 diffractometer with $\mathrm{CuK} \alpha=1.5417 \AA$, operated at $40 \mathrm{kV}$ and $30 \mathrm{~mA}$. The diffraction patterns were recorded in the $2 \theta$ range of $10-90^{\circ}$ with a step interval of $0.02^{\circ}$ and period of $1 \mathrm{~s}$.

Gas phase components were analyzed on-line by gas chromatography equipped with FID (oxygenated products) and TCD detectors (hydrogen, carbon monoxide, carbon dioxide, methane). The reaction was performed during one hour.

All the experiments were performed three times after cleaning the inner electrode and changing the catalyst (when used), a margin error of $\pm 3 \%$ was calculated.

The conversion, selectivity, yields and energy efficiency were defined as:

Conversion (\%) of $\mathrm{CH}_{4}$ and $\mathrm{CO}_{2}=100 \times$ mole of $\mathrm{CH}_{4}\left(\right.$ or $\left.\mathrm{CO}_{2}\right)$ converted/ mole of $\mathrm{CH}_{4}$ (or $\left.\mathrm{CO}_{2}\right)$ in the feed

The selectivity was calculated based on carbon atoms:

Selectivity to $\mathrm{C}_{\mathrm{n}} \mathrm{H}_{\mathrm{y}}(\%)=100 \times \mathrm{n} \times$ mole of $\mathrm{C}_{\mathrm{n}} \mathrm{H}_{\mathrm{y}} /\left(\right.$ mole of $\mathrm{CH}_{4}$ converted + mole of $\mathrm{CO}_{2}$ converted)

Selectivity to $\mathrm{CO}(\%)=100 \times$ mole of $\mathrm{CO} /\left(\right.$ mole of $\mathrm{CH}_{4}+$ mole of $\left.\mathrm{CO}_{2}\right)$ converted Yield in $\mathrm{H}_{2}(\%)=100 \times$ mole of $\mathrm{H}_{2} / 2 *\left(\right.$ mole of $\left.\mathrm{CH}_{4}\right)$ introduced

Carbon Balance: $\mathrm{CB}(\%)=100 \times\left(\right.$ mole of $\mathrm{CO}+\sum \mathrm{n} \times$ mole of $\left.\mathrm{C}_{\mathrm{n}} \mathrm{H}_{\mathrm{y}}\right) /\left(\right.$ mole of $\mathrm{CH}_{4}$ converted + mole of $\mathrm{CO}_{2}$ converted) 


\section{Results and discussion}

\subsection{Preliminary results}

First experiments were performed by filling the plasma zone with quartz wool at room temperature, 100,200 and $300^{\circ} \mathrm{C}$, with different $\mathrm{CH}_{4} / \mathrm{CO}_{2}$ ratio $(0.5,1,2)$. It was decided to fill the plasma reactor with quartz wool instead to keeping the plasma zone empty in order to obtain more accurate data in terms of residence time when compared with the presence of catalysts. Moreover the nature of plasma discharge is also modified in the presence of materials. Compared with an empty reactor, the presence of quartz wool (dielectric constant close to 4) causes an increase of the average electron energy but a decrease of electron density, improving the electric field strength but decreasing the amount of microdischarges [20, 21]. A higher conversion is expected with dielectric materials in the discharge, but it could be compensated by the lower contact time of reactant induced by the filling of the plasma zone [22]. Moreover all the experiments were performed using helium as a dilution gas (75\% vol.). Using a constant flow of helium as diluent allow to obtain a more homogeneous plasma discharge. Indeed, Ozkan et al. [23], showed that a glow discharge was obtained with helium while a filamentary discharge is observed in the presence of argon. Moreover, the authors showed that the glow regime (with $\mathrm{He}$ ) favors $\mathrm{CH}_{4}$ dissociation since the number of electrons participating to $\mathrm{C}-\mathrm{H}$ bond breaking is much higher in a glow discharge than in a filamentary one. The role of helium to perform activation under plasma discharge is also explained by a transfer of charges and energy from $\mathrm{He}$ species such as $\mathrm{He}^{+}$or $\mathrm{He}^{2+}$ to $\mathrm{CH}_{4}$ and $\mathrm{CO}_{2}$, leading to the formation of vibrationally excited species such as $\mathrm{CH}_{4}{ }^{+}$and $\mathrm{CO}_{2}{ }^{+}$increasing, then, their reactivity [24].

$\mathrm{CH}_{4}, \mathrm{CO}_{2}$ conversions and selectivity to products are gathered in Figures 4 and Table 1 respectively. It appears that methane conversion is always higher than $\mathrm{CO}_{2}$ conversion independently of the reaction temperature and the ratio $\mathrm{CH}_{4} / \mathrm{CO}_{2}$. The excited oxygen atomic species generated from $\mathrm{CO}_{2}$ promotes conversion of $\mathrm{CH}_{4}$ leading to methyl and hydroxyl 
radicals [25]. Moreover conversions are not significantly modified within the temperature range used in this study, while the selectivity to products are strongly influenced by the temperature and $\mathrm{CH}_{4} / \mathrm{CO}_{2}$ ratio. As expected and reported elsewhere $[26,27]$ the selectivity to $\mathrm{CO}$ is maximum using $\mathrm{CO}_{2}$ in excess and the selectivity to hydrocarbons (mainly ethane) is the highest in an excess of methane in the feed. Note that carbon balance is maximum for the ratio $\mathrm{CH}_{4} / \mathrm{CO}_{2}$ $=0.5$, closed to $99 \%$ at room temperature, while for $\mathrm{CH}_{4} / \mathrm{CO}_{2}=2$ the carbon balance is lower than $90 \%$ and a deposition was visible at the surface of the inner electrode. An increase of the temperature until $300^{\circ} \mathrm{C}$ leads to a significant decrease in $\mathrm{CO}$ selectivity for both experiments in excess of $\mathrm{CO}_{2}$ and $\mathrm{CH}_{4}$ while with the stoichiometric mixture, the influence of temperature is not clear. The selectivity to oxygenate compounds decreases when the temperature increases and the carbon deposition occurs more readily at higher temperature.

2.2 Methane and carbon dioxide transformation over calcium oxide under plasma discharge

\subsubsection{Influence of the grain size and role of $\mathrm{CaO}$ material}

The influence of the grain size was studied using $\mathrm{CaO}$ oxide after calcination at $800^{\circ} \mathrm{C}$ in order to eliminate carbonate and hydrogeno-carbonate species. The $\mathrm{CaO}$ powder was sieved and separated into four different samples with diameters d1: 250-355 $\mu \mathrm{m}, \mathrm{d} 2: 355-650 \mu \mathrm{m}, \mathrm{d} 3: 650-$ 800 and d4: $800-1000 \mu \mathrm{m}$. Note that if we consider a compact filling of the reactor with spherical particles, the weight of materials and the total volume of gas between the grains are not modified. The parameters that are affected by the grain size are the accessible surface, the average size of space between particles and the number of contact point between the particles. The results reported in Figure 5, obtained in the presence of an excess of $\mathrm{CO}_{2}\left(\mathrm{CH}_{4} / \mathrm{CO}_{2}=0.5\right)$, show that conversion of $\mathrm{CO}_{2}$ and $\mathrm{CH}_{4}$ increased with decreasing particle size. Methane conversion is closed to $30 \%$ in the presence of the smallest $\mathrm{CaO}$ grains, while with quartz wool 
methane conversion was lower than $20 \%, \mathrm{CO}_{2}$ conversion was $16 \%$ and $12 \%$ with and without $\mathrm{CaO}$ respectively.

Kasinathan et al. [28] obtained a similar effect of particle size for $\mathrm{CH}_{4}$ conversion into $\mathrm{C} 2, \mathrm{C} 3$ and $\mathrm{C} 4$ hydrocarbons over $\mathrm{MgO} / \mathrm{Al}_{2} \mathrm{O}_{3}$. The authors, using an ICCD camera, showed that the smaller the catalyst particle used, the lighter the plasma observed on the catalyst surface. An improved interaction between the surface of the oxide and the plasma was proposed for the smallest catalyst grains. The exact role of the surface of the oxide is difficult to determine since some reactions involved can be performed in gas phase as at the surface of the oxide, by example $\mathrm{CO}$ can be obtained directly by $\mathrm{CO}_{2}$ splitting and also after $\mathrm{CO}_{2}$ adsorption at the surface of the basic $\mathrm{CaO}$ according to:

$\mathrm{CO}_{2}+* \rightarrow \mathrm{CO}_{2 \text { ads }}$

$\mathrm{CO}_{2 \mathrm{ads}} \rightarrow \mathrm{CO}+\mathrm{O}_{\text {ads }}($ under plasma $)$

$\left(\mathrm{CH}_{\mathrm{x}}\right)+\mathrm{O}_{\mathrm{ads}} \rightarrow \mathrm{CO}_{\mathrm{ads}}+\mathrm{x} /{ }_{2} \mathrm{H}_{2}$

The selectivity to products depends on the particle size (Table 2), ethane formation is favored when the biggest particles are used, so when the space between grains is the largest, suggesting that the recombination of $\mathrm{CH}_{3}$ radicals to form $\mathrm{C}_{2} \mathrm{H}_{6}$ is favored in gaseous phase and not at the surface of the solid. Note that the carbon balance is high, always higher than $90 \%$, the carbon deposition is limited under the experimental conditions used (excess of $\mathrm{CO}_{2}$ ). As expected, $\mathrm{CO}$ is the main product formed while the amount of oxygenated products is low whatever the grain size.

According to the results obtained here, it is believed that the reactivity is governed by the characteristics of the discharge at the external surface of the packing material possessing a low dielectric constant $(\approx 11[29])$. $\mathrm{CaO}$ calcined at $800^{\circ} \mathrm{C}$ is characterized by the presence of meso and macropores with porous volume of $0.01 \mathrm{~cm}^{3} / \mathrm{g}$ and an average pore diameter of $20 \mathrm{~nm}$ (determined by adsorption/desorption of nitrogen). The specific surface area of $\mathrm{CaO}$ is low after 
calcination at $800^{\circ} \mathrm{C}: 1.8 \mathrm{~m}^{2} / \mathrm{g}$ (Table 4). In DBD plasma conditions, the formation of microdischarges in pores is possible when their diameter is larger than the Debye length. This value depends on electron density and temperature in the plasma streamer but is typically in the order of $100 \mathrm{~nm}$ to $1 \mu \mathrm{m}$. According to calculations performed by the group of A. Bogaerts, plasma can penetrate in pores of about $50 \mathrm{~nm}$ but only in some extent and at very short time [30, 31]. Consequently, using $\mathrm{CaO}$ the penetration of micro-discharges within pores can be excluded.

\subsubsection{Influence of the ratio $\mathrm{CH}_{4} / \mathrm{CO}_{2}$}

The reaction was carried out at room temperature by filling the plasma zone with calcium oxide powder calcined at $800^{\circ} \mathrm{C}$, sieved in the range: $355 \mu \mathrm{m}<\mathrm{d}<650 \mu \mathrm{m}$, the deposited power was fixed at $8 \mathrm{~W}$ and the helium concentration was $75 \%$. A similar trend, as reported for the experiments using quartz wool, is observable: the carbon balance and the selectivity to $\mathrm{CO}$ is maximum with an excess of $\mathrm{CO}_{2}$ (Table 3). Besides $\mathrm{CO}$ and hydrocarbons, oxygenated products were formed from $\mathrm{CH}_{4}$ and $\mathrm{CO}_{2}$ mixture. The main oxygenates quantified were formaldehyde, methanol, acetaldehyde and ethanol, however the selectivities are very low under the experimental conditions used in this study. An opposite trend is visible concerning formaldehyde and methanol formation: $\mathrm{CH}_{3} \mathrm{OH}$ is slightly favored when an excess of $\mathrm{CO}_{2}$ is used, while the formation of $\mathrm{HCOH}$ is favored in an excess of methane. These results are in agreement with the reported research of De Bie et al. using a one-dimensional fluid model [32]. The dominant reaction pathways for the production of methanol was indicated by the authors, methanol being produced through the following three-body reaction between $\mathrm{CH}_{3}$ and $\mathrm{OH}$ radicals: $\mathrm{CH}_{3}+\mathrm{OH}+\mathrm{M} \rightarrow \mathrm{CH}_{3} \mathrm{OH}+\mathrm{M}$. It is also supported by the work of Wang et al. based on density functional theory (DFT) calculations [33] and Istadi who used a hybrid artificial neural network - genetic algorithm technique [34]. The production of formaldehyde comes from the reaction between $\mathrm{CO}_{2}$ and $\mathrm{CH}_{2}$ radicals and acetaldehyde is obtained by $\mathrm{O}$ atom (from $\mathrm{CO}_{2}$ dissociation) reaction with ethyl radical [32]. 


\subsubsection{Influence of temperature}

A previous study performed in our team [14] shows that an increase of temperature at $300^{\circ} \mathrm{C}$ favors the conversion of $\mathrm{CH}_{4}$ and $\mathrm{CO}_{2}$ at the surface of balls composed of $\mathrm{La}_{2} \mathrm{O}_{3} / \mathrm{Al}_{2} \mathrm{O}_{3}$. It was thus interesting to investigate the influence of temperature on reactant conversion and product selectivities in the presence of calcium oxide calcined at $800^{\circ} \mathrm{C}$. The results obtained for grain size: $355 \mu \mathrm{m}<\mathrm{d}<650 \mu \mathrm{m}, \mathrm{P}=8 \mathrm{~W}$, from 100 to $300^{\circ} \mathrm{C}$ and a $\mathrm{CH}_{4} / \mathrm{CO}_{2}$ ratio of 2 are gathered in figure 6. It is observed that methane conversion is relatively stable during time on stream and is closed to $20 \%$ whatever the reaction temperature, while with quartz wool methane conversion decreases regularly at 100 and $200^{\circ} \mathrm{C}$, until $13.6 \%$ after 50 minutes at $100^{\circ} \mathrm{C}$. The carbon balance is significantly higher in the presence of $\mathrm{CaO}$ where it is maintained closed to $80 \%$ at 100 and $200^{\circ} \mathrm{C}$, while it falls at $68.2 \%$ without catalyst after 30 minutes. Consequently, the results show that the presence of $\mathrm{CaO}$ limits carbon deposition, which is clearly observable at the surface of the electrode when the reactor is filled with quartz wool. At $300^{\circ} \mathrm{C}$, the behavior is completely different: $\mathrm{CO}_{2}$ conversion is strongly increased at the beginning of the experiment performed at $300^{\circ} \mathrm{C}$, reaching $40 \%$, then it decreases regularly with time and stabilizing at around $15 \%$ after 30 minutes. The carbon balance follows an opposite trend suggesting a reaction of $\mathrm{CO}_{2}$ with the basic $\mathrm{CaO}$ material. The selectivity to the main products: $\mathrm{CO}$ and $\mathrm{C}_{2} \mathrm{H}_{6}$ is not modified by the increase of the reaction temperature. Note that methane conversion is not significantly increased in the presence of $\mathrm{CaO}$ compared to quartz wool, so the adsorption of $\mathrm{CO}_{2}$ during the first minutes of reaction at $300^{\circ} \mathrm{C}$ is not favorable for the activation of methane at the surface of the catalyst. It suggests that the carbonation of $\mathrm{CaO}$ (evidenced by TDA-TGA analysis, see below) leads to the formation of stable species that do not favor $\mathrm{CO}_{2}$ dissociation, nor the further reaction between adsorbed oxygen species and activated methane, contrary to what was proposed when using $\mathrm{La}_{2} \mathrm{O}_{3} / \mathrm{Al}_{2} \mathrm{O}_{3}[14]$. 
Moreover, little modifications are observable on oxygenates, an increase in the reaction temperature lead to a decrease of the selectivity to methanol and formaldehyde while the selectivity to acetaldehyde is not strongly modified.

\subsection{Characterization of the oxide after reaction at different temperatures}

\subsubsection{XRD analysis and surface area}

The catalyst was characterized by XRD before and after experiments under plasma in an excess of methane at 100,200 and $300^{\circ} \mathrm{C}$. The results are gathered in Figure 7 . Before reaction, as expected, the phase identified was $\mathrm{CaO}$ (ICSD 98-009-0486). After exposure to a mixture of $\mathrm{CH}_{4}$ and $\mathrm{CO}_{2}$ under plasma at $100^{\circ} \mathrm{C}$, no significant differences are observed, the main phase identified being $\mathrm{CaO}$. At 200 and $300^{\circ} \mathrm{C}$, peaks assigned to $\mathrm{Ca}(\mathrm{OH})_{2}$ (ICSD 98-007-3467) and $\mathrm{CaCO}_{3}$ (ICSD 98-004-0543) are clearly visible. The results show undoubtedly that hydration and carbonation of calcium oxide proceeds under plasma discharge at 200 and $300^{\circ} \mathrm{C}$ while the catalyst seems not significantly modified at room temperature and $100^{\circ} \mathrm{C}$ after one hour under plasma. The specific surface area of the materials used was very low: $1.8 \mathrm{~m}^{2} / \mathrm{g}$ (Table 4). It seems that after reaction under plasma, the surface area slightly increased reaching $2.7 \mathrm{~m}^{2} / \mathrm{g}$ when the reaction was performed at $200^{\circ} \mathrm{C}$, the calcium hydroxide particles formed during reaction occupying a larger molar volume. Note that the pore size was very low for the starting material $(20 \mathrm{~nm})$ and no significant differences were observed in porosity after reaction under plasma whatever the reaction temperature.

\subsubsection{TGA-TDA analysis and carbonation}

The catalyst recovered after reaction at room temperature, 100,200 and $300^{\circ} \mathrm{C}$ did not exhibit significant differences in colors (Figure 8), only the catalyst after reaction at $300^{\circ} \mathrm{C}$ appears a little bit greyer, it attests that the carbon deposition is very limited when using $\mathrm{CaO}$ and plasma. 
TGA-TDA analysis were performed after one hour of reaction under plasma discharge using calcium oxide calcined at $800^{\circ} \mathrm{C}$, with grain size: $355 \mu \mathrm{m}<\mathrm{d}<650 \mu \mathrm{m}, \mathrm{P}=8 \mathrm{~W}$, from room to $300^{\circ} \mathrm{C}$ and a $\mathrm{CH}_{4} / \mathrm{CO}_{2}$ ratio of 2 (Figure 9). No significant differences are observed before reaction and after reaction at room temperature as at $100^{\circ} \mathrm{C}$. The weight loss between 500 $700^{\circ} \mathrm{C}$ is attributed to the presence of stable carbonate species, the carbonation of $\mathrm{CaO}$ observed for the solid before reaction proceeds during the transfer step from the calcined oven to the plasma reactor. When the reaction is performed at $200^{\circ} \mathrm{C}$, TGA profile exhibits an important weight loss between $300-500^{\circ} \mathrm{C}(6.1 \%)$ corresponding to an endothermic peak. It is attributed to the decomposition of $\mathrm{Ca}(\mathrm{OH})_{2}$ [35]. The formation of calcium hydroxide can result from $\mathrm{H}_{2} \mathrm{O}$ dissociation to $\mathrm{H}^{+}, \mathrm{OH}^{-}$in gas phase since water is widely formed under our experimental conditions through the reverse water gas shift reaction.

After reaction at $300^{\circ} \mathrm{C}$, the presence of calcium carbonate is preponderant. The absorption capacity of $\mathrm{CaO}$, corresponding to the ratio of $\mathrm{CO}_{2}$ captured/CaO (weight \%), under plasma, determined after one hour on stream is equal to $7.5 \%$ at $300^{\circ} \mathrm{C}$.

From the data collected by TGA analysis it was possible to indicate the number of theoretical monolayers of $\mathrm{CaO}$ covered by $\mathrm{Ca}(\mathrm{OH})_{2}$ and $\mathrm{CaCO}_{3}$. The approximation made is that the coverage is homogeneous at the surface of the solid, while an irregular coverage is more likely. However, such calculations allow to show how phase modifications occurs under plasma depending on the experimental conditions used. The calculation was performed knowing that $\mathrm{CaO}$ crystallizes with a face-centered cubic structure $(\mathrm{NaCl}$ type) with a lattice parameter $\mathrm{a}=$ $4.81 \AA$. The results reported in Table 4 show that the amount of absorbed $\mathrm{CO}_{2}$ corresponds to 59 monolayers, showing that $\mathrm{CO}_{2}$ or activated $\mathrm{CO}_{2}$ species are able to diffuse within $\mathrm{CaO}$ under plasma discharge at $300^{\circ} \mathrm{C}$. The diffusion of reactive plasma species deep into porous catalysts, with pore size of $10 \mathrm{~nm}$ was proposed by Holzer et al. [36]. 
It is known that the carbonation reaction of $\mathrm{CaO}$ is exothermic $\left(\mathrm{CaO}(\mathrm{s})+\mathrm{CO}_{2}(\mathrm{~g})=\mathrm{CaCO}_{3}(\mathrm{~s})\right.$ $\Delta \mathrm{H}_{\mathrm{r}, 298 \mathrm{~K}}=-178 \mathrm{~kJ} / \mathrm{mol}$ ) and is possible within a large range of temperatures. Kinetically the carbonation of $\mathrm{CaO}$ proceeds in two successive steps, a fast one followed by a slow one. The reaction is controlled by the reaction between $\mathrm{CaO}$ and $\mathrm{CO}_{2}$ leading to the formation of a layer of $\mathrm{CaCO}_{3}$ covering the remaining $\mathrm{CaO}$, that constitutes a diffusional resistance for $\mathrm{CO}_{2}$ reaction, switching the carbonation reaction from a fast step to a slow one controlled by gas diffusion [37]. Practically, $\mathrm{CO}_{2}$ sorption is performed in the so called carbonator [38] at temperatures above $500^{\circ} \mathrm{C}$ in order to limit the effect of diffusion limitation. Moreover, the steam effect at low temperature was reported by Wang et al. [39], the authors showed that carbonation of $\mathrm{CaO}$ is possible between 250 and $400^{\circ} \mathrm{C}$, while no $\mathrm{CaO}$ carbonation would occur without the presence of water at these temperatures. A two-step route is proposed when $\mathrm{H}_{2} \mathrm{O}$ vapor is present in the feed gas: $\mathrm{CaO} \rightarrow \mathrm{Ca}(\mathrm{OH})_{2} \rightarrow \mathrm{CaCO}_{3}$. However at low temperature $\left(300^{\circ} \mathrm{C}\right)$, the kinetic of $\mathrm{CaO}$ carbonation is slow since 200 minutes are required to reach a conversion rate of $8 \%$, in the presence of water $(8 \mathrm{vol} \%)$ [39], while under nonthermal plasma carbonation of $\mathrm{CaO}$ proceeds rapidly during the first minutes of experiments.

\section{Conclusion}

In this study calcium oxide was used in association with plasma discharge to perform the transformation of methane and carbon dioxide. We showed that the $\mathrm{CaO}$ grain size influences strongly $\mathrm{CH}_{4}$ and $\mathrm{CO}_{2}$ conversion, the lowest particle size favoring reactant transformation, while the selectivity to oxygenates remains low $(<2 \%)$ whatever the size of $\mathrm{CaO}$ grains for a $\mathrm{CH}_{4} / \mathrm{CO}_{2}$ ratio $=0.5$. Nevertheless, the selectivity to ethane is maximum as soon as the space between grains is maximum (bigger particles) which is attributed to the recombination of radical species in gas phase. The use of methane in excess $\left(\mathrm{CH}_{4} / \mathrm{CO}_{2}=2\right)$ favors the formation of oxygenates compounds even if the selectivity remains low: $2.4 \%$, the main oxygenated 
product being acetaldehyde. When performing the reaction at $300^{\circ} \mathrm{C}$, catalyst structural modification are observed and the carbonation of $\mathrm{CaO}$ proceeds. The amount of carbonate species was quantified and the results show that 59 monolayers of $\mathrm{CaCO}_{3}$ are obtained after one hour of plasma at $\mathrm{P}=8 \mathrm{~W}$ using a mixture with a $\mathrm{CH}_{4} / \mathrm{CO}_{2}$ ratio of 2 . It proves that the $\mathrm{CO}_{2}$ molecules are able to diffuse rapidly into the small $\mathrm{CaO}$ pores at $300^{\circ} \mathrm{C}$ under the plasma discharge.

\section{Acknowledgements}

The authors grateful acknowledge the ANR for the financial support of the PRC program VALCO2PLAS 


\section{References}

[1] J.R. Rostrup-Nielsen, J. Sehested, J.K. Norskov, Adv. Catal. 47 (2002) 65-139

[2] S.C. Tsang, J.B. Claridge, M.L.H. Green, Catal. Today, 23 (1995) 3-15

[3] Z. Hou, P. Chen, H. Fang, X. Zheng, T. Yashima, Int. J. Hydrog. Energy. 31 (2006) 555561

[4] Z. Wang, X.-M. Cao, J. Zhu, P. Hu, J. Catal. 311 (2014) 469-480

[5] Y.H. Hu, E. Ruckenstein, Adv. Catal. 48 (2004) 297-345

[6] M. Kraus, W. Egli, K. Haffner, B. Eliasson, U. Kogelschatz, A. Wokaun, Phys. Chem. Chem. Phys. 4 (2002) 668-675

[7] B. Wang, G. Xu, J. Nat. Gas Chem. 12 (2003) 178-182

[8] B. Eliasson, W. Egli, U. Kogelschatz, Pure Appl. Chem. 66(6) (1994) 1275-1286

[9] E.C. Neyts, K. Ostrikov, M.K. Sunkara, A. Bogaerts, Chem. Rev. 115 (2015) 1340813446

[10] X. Tu, H.J. Gallon, M. V. Twigg, P. A. Gorry, J.C. Whitehead, J.Phys. D: Appl. Phys. 44 (2011) 274007-274017

[11] S. Jo, T. Kim, D.H. Lee, W.S. Kang, Y.H. Song, Plasma Chem. Plasma Process. 34 (2014) 175-186

[12] M. Scapinello, E. Delikonstantis, G. D. Stefanidis, Chem. Eng. Process. Intensification 117 (2017) 120-140

[13] V. Goujard, J.M. Tatibouët, C. Batiot-Dupeyrat, IEEE Transactions on Plasma Science, 37 (12) (2009) 2342-2346

[14] D. Yap, J.M. Tatibouët, C. Batiot-Dupeyrat, Catal. Today, 299 (2018) 263-271

[15] N.N. Gadzhieva, High energy chemistry, 37 (1) (2003) 43-49

[16] X. Zheng, S. Tan, L. Dong, S. Li, H. Chen, Journal of Power Sources 274 (2015) 286294 
[17] T. Jiang, Y. Li, C.J. Liu, G.H. Xu, B. Eliasson, B. Xue, Catal. Today, 72 (2002) 229-235

[18] X. Zhang, B. Dai, A. Zhu, W. Gong, C. Liu, Catal. Today, 72 (2002) 223-227

[19] W. Wang, H.H. Kim, K. Van Laer, A. Bogaerts, Chem. Eng. J 334 (2018) 2467-2479

[20] H.L. Chen, H.M. Lee, S.H. Lee, Ind. Eng. Chem. Res. 47(2008) 2122-2130

[21] Q. Yu, M. Kong, T. Liu, J. Fei, X. Zheng, Plasma Chem. Plasma Process. 32 (2012) 153163

[22] V. Goujard, J.M. Tatibouët, C. Batiot-Dupeyrat, Appl. Catal. A : Gen, 353 (2009) 228235

[23] A. Ozkan, T. Dufour, G. Arnoult, P. De Keyzer, A. Bogaerts, F. Reniers, J. $\mathrm{CO}_{2}$ utilization 9 (2015) 74-81

[24] S.L. Brock, M. Marquez, S.L. Suib, Y. Hayashi, H. Matsumoto, J. Catal. 180 (1998) $225-233$

[25] X. Tu, J. C. Whitehead, Int. J. Hydrogen En. 39 (2014) 9658-9669

[26] A. J. Zhang, A. M. Zhu, J. Guo, Y. Xu, C. Shi, Chem. Eng. J. 156 (2010) 601-606

[27] W.C. Chung, K. L. Pan, H.M. Lee, M.B. Chang, Energy and Fuel, 28 (2014) 7621-7631 [28] P. Kasinathan, S. Park, W.C. Choi, Y.K. Hwang, J.S. Chang, Y.K. Park, Plasma Chem. Plasma process. 34 (2014) 1317-1330

[29] J. Robertson, Eur. Phys. J. Appl. Phys. 28 (2004) 265-291

[30] Y.R. Zhang, K.Van Laer, E. C. Neyts, A. Bogaerts, Appl. Catal. B: Env 185 (2016) 5667

[31] Q.Z. Zhang, A. Bogaerts, Plasma Sources Sci. technol. 27 (2018) 35009-35019

[32] C. De Bie, J. Van Dijk, A. Bogaerts, J. Phys. Chem. C 119 (2015) 22331-22350

[33] J.G. Wang, C. Liu, B. Eliassion, Energy Fuels, 18 (2004) 148-153

[34] I. Istadi, N.A.S. Amin, Chem. Eng. Sci. 62 (2007) 6568-6581 
[35] Z. Mirghiasi, F. Bakhtiari, E. Darezereshki, E. Esmaeilzadeh, J. Ind. Eng. Chem. 20 (2014) 113-117

[36] F. Holzer, U. Roland, F.D. Kopinke, Appl. Catal. B: Env. 38 (2002) 163-181

[37] J.C. Abanades, D. Alvarez, Energy and Fuels, 17 (2003) 308-315

[38] D. K. Lee, Chem. Eng. J., 100 (2004) 71-77

[39] C. Wang, L. Jia, Y. Tan, E. Anthony, Fuel, 87 (7) (2008) 1108-1114 
List of Tables:

\begin{tabular}{|c|c|c|c|c|c|c|c|c|c|c|}
\hline \multirow{2}{*}{$\mathrm{CH}_{4} / \mathrm{CO}_{2}$} & \multirow{2}{*}{$\begin{array}{c}\text { Temp. } \\
{ }^{\circ} \mathrm{C}\end{array}$} & \multirow{2}{*}{$\begin{array}{l}\text { Yield in } \\
\mathrm{H}_{2}(\%)\end{array}$} & \multicolumn{7}{|c|}{ Selectivity (\%) } & \multirow{2}{*}{$\begin{array}{l}\text { C. B. } \\
(\%)\end{array}$} \\
\hline & & & $\mathrm{CO}$ & $\mathrm{C}_{2} \mathrm{H}_{6}$ & $\mathrm{C}_{3} \mathrm{H}_{8}$ & $\mathrm{HCOH}$ & $\mathrm{AcOH}$ & $\mathrm{MeOH}$ & $\mathrm{EtOH}$ & \\
\hline \multirow{4}{*}{0.5} & room & 9.4 & 80.3 & 13.6 & 0.9 & 1.8 & 0.4 & 0.6 & 0.2 & 98.6 \\
\hline & 100 & 9.0 & 72.1 & 12.9 & 0.8 & 1.2 & 0.3 & 0.5 & 0.2 & 88.7 \\
\hline & 200 & 11.0 & 71.9 & 14.5 & 1.3 & 1.0 & 0.6 & 0.4 & 0.2 & 90.6 \\
\hline & 300 & 10.3 & 68.7 & 13.8 & 1.2 & 0.7 & 0.6 & 0.4 & 0.1 & 86.3 \\
\hline \multirow{4}{*}{1} & room & 7.2 & 58.1 & 19.6 & 2.2 & 2.0 & 0.8 & 0.6 & 0.3 & 85.0 \\
\hline & 100 & 6.6 & 55 & 20.1 & 2.5 & 2.0 & 1.0 & 0.5 & 0.3 & 83.0 \\
\hline & 200 & 7.3 & 55.2 & 22.5 & 3.6 & 2.0 & 1.3 & 0.6 & 0.3 & 87.5 \\
\hline & 300 & 7.7 & 60.9 & 26.7 & 3.5 & 1.2 & 1.2 & 0.5 & 0.2 & 97.6 \\
\hline \multirow{4}{*}{2.0} & room & 6.1 & 50.2 & 26.3 & 5.5 & 2.4 & 2.4 & 1.3 & 0.4 & 86.5 \\
\hline & 100 & 5.8 & 41.0 & 27.5 & 4.3 & 1.6 & 1.8 & 0.4 & 0.3 & 80.2 \\
\hline & 200 & 6.6 & 32.3 & 25.1 & 4.1 & 1.1 & 1.7 & 0.5 & 0.2 & 68.2 \\
\hline & 300 & 6.2 & 30.2 & 25.7 & 4.8 & 1.0 & 1.9 & 0.5 & 0.2 & 66.7 \\
\hline
\end{tabular}

Table1: Influence of the $\mathrm{CH}_{4} / \mathrm{CO}_{2}$ ratio and temperature on product selectivity and hydrogen yield (average value, reaction time: 30 minutes), $\mathrm{P}=8 \mathrm{~W}$, total flow: $40 \mathrm{~mL} / \mathrm{min}, \mathrm{He}: 75 \%$.

\begin{tabular}{|c|c|c|c|c|c|c|}
\hline \multirow{2}{*}{$\begin{array}{c}\text { Particle size } \\
\mu \mathrm{m}\end{array}$} & \multirow{2}{*}{$\begin{array}{c}\mathrm{H}_{2} \\
\text { yield }\end{array}$} & \multicolumn{4}{|c|}{ Selectivity (\%) } & \multirow{2}{*}{$\begin{array}{c}\text { Carbone } \\
\text { balance (\%) }\end{array}$} \\
\hline & & $\mathrm{CO}$ & $\mathrm{C}_{2} \mathrm{H}_{6}$ & $\mathrm{MeOH}$ & $\mathrm{EtOH}$ & \\
\hline $\mathrm{d} 1: 250-355$ & 12.2 & 76.8 & 8.4 & 0.8 & 0.2 & 90 \\
\hline $\mathrm{d} 2: 355-650$ & 10.6 & 80.9 & 10.8 & 1.0 & 0.3 & 97 \\
\hline d3: $650-800$ & 9.7 & 76.8 & 11.2 & 0.8 & 0.3 & 93 \\
\hline $\mathrm{d} 4: 800-1000$ & 9.4 & 75.6 & 11.7 & 0.8 & 0.2 & 92 \\
\hline
\end{tabular}

Table 2: Influence of the grain size on product selectivity and hydrogen yield (average value, reaction time: 30 minutes), $\mathrm{CaO}$ calcined at $800^{\circ} \mathrm{C}$ before reaction, $\mathrm{d} 1: 250-355 \mu \mathrm{m}, \mathrm{d} 2: 355-$ $650 \mu \mathrm{m}, \mathrm{d} 3: 650-800, \mathrm{~d} 4: 800-1000 \mu \mathrm{m}, \mathrm{P}=8 \mathrm{~W}$, total flow: $40 \mathrm{~mL} / \mathrm{min}, \mathrm{He}: 75 \%$, ratio $\mathrm{CH}_{4} / \mathrm{CO}_{2}$ $=0.5$

\begin{tabular}{|c|c|c|c|c|c|c|c|c|c|c|c|}
\hline \multirow{2}{*}{$\mathrm{CH}_{4} / \mathrm{CO}_{2}$} & \multicolumn{2}{|c|}{$\begin{array}{c}\text { Conversion } \\
(\%)\end{array}$} & \multirow{2}{*}{$\begin{array}{c}\mathrm{H}_{2} \\
\text { yield } \\
(\%)\end{array}$} & \multicolumn{7}{|c|}{ Selectivity (\%) } & \multirow{2}{*}{$\begin{array}{l}\text { CB } \\
(\%)\end{array}$} \\
\hline & $\mathrm{CO}_{2}$ & $\mathrm{CH}_{4}$ & & $\mathrm{CO}$ & $\mathrm{C}_{2} \mathrm{H}_{6}$ & $\mathrm{C}_{3} \mathrm{H}_{8}$ & $\mathrm{HCOH}$ & $\mathrm{AcOH}$ & $\mathrm{MeOH}$ & $\mathrm{EtOH}$ & \\
\hline 0.5 & 12.0 & 24.4 & 10.6 & 80.9 & 10.8 & 1.2 & 1.5 & 0.3 & 1.0 & 0.3 & 96.0 \\
\hline 1 & 12.4 & 21.4 & 7.6 & 63.6 & 17.8 & 2.1 & 1.8 & 0.7 & 0.8 & 0.3 & 88.5 \\
\hline 2 & 10.3 & 17.5 & 6.1 & 45.5 & 27.1 & 3.6 & 1.9 & 1.3 & 0.7 & 0.4 & 83.1 \\
\hline
\end{tabular}

Table 3: Influence of the $\mathrm{CH}_{4} / \mathrm{CO}_{2}$ ratio on product selectivity and hydrogen yield (average value, reaction time: 30 minutes), $\mathrm{CaO}$ calcined at $800^{\circ} \mathrm{C}$ before reaction, grain size: 355 $650 \mu \mathrm{m}, \mathrm{P}=8 \mathrm{~W}$, total flow: $40 \mathrm{~mL} / \mathrm{min}, \mathrm{He}: 75 \%$. 


\begin{tabular}{|c|c|c|c|c|c|c|c|}
\hline \multirow[t]{2}{*}{ condition } & \multirow{2}{*}{$\begin{array}{l}\mathrm{S}_{\mathrm{BET}} \\
\mathrm{m}^{2} / \mathrm{g}\end{array}$} & \multicolumn{2}{|c|}{ Weight loss (\%) } & \multicolumn{2}{|c|}{$\operatorname{Mol}(\%)$} & \multicolumn{2}{|c|}{$\begin{array}{l}\text { Number of } \\
\text { monolayers }\end{array}$} \\
\hline & & $300-500^{\circ} \mathrm{C}$ & $500-700^{\circ} \mathrm{C}$ & $\mathrm{Ca}(\mathrm{OH})_{2}$ & $\mathrm{CaCO}_{3}$ & $\mathrm{Ca}(\mathrm{OH})_{2}$ & $\mathrm{CaCO}_{3}$ \\
\hline Before plasma & 1.8 & 0 & 2.2 & 0 & 2.9 & 0 & 17 \\
\hline RT & 2.0 & 0 & 2.2 & 0 & 2.9 & 0 & 17 \\
\hline After $\quad \underline{T=100^{\circ} \mathrm{C}}$ & 2.5 & 0 & 2.2 & 0 & 2.9 & 0 & 17 \\
\hline plasma $\overline{\mathrm{T}=200^{\circ} \mathrm{C}}$ & 2.7 & 6.1 & 4.3 & 21 & 6 & 24 & 34 \\
\hline$(1$ hour $) \overline{\mathrm{T}=300^{\circ} \mathrm{C}}$ & 2.0 & 2.2 & 7.5 & 7.6 & 10.6 & 9 & 59 \\
\hline
\end{tabular}

Table 4: Characterization of the $\mathrm{CaO}$ catalyst after plasma treatment, number of layers formed according to TGA analysis, reaction conditions: $\mathrm{CaO}$ calcined at $800^{\circ} \mathrm{C}$, grain size: $355-650 \mu \mathrm{m}$, $\mathrm{P}=8 \mathrm{~W}$, total flow: $40 \mathrm{~mL} / \mathrm{min}, \mathrm{He}: 75 \%$, ratio $\mathrm{CH}_{4} / \mathrm{CO}_{2}=2$ 
Figure 1: Reactor scheme

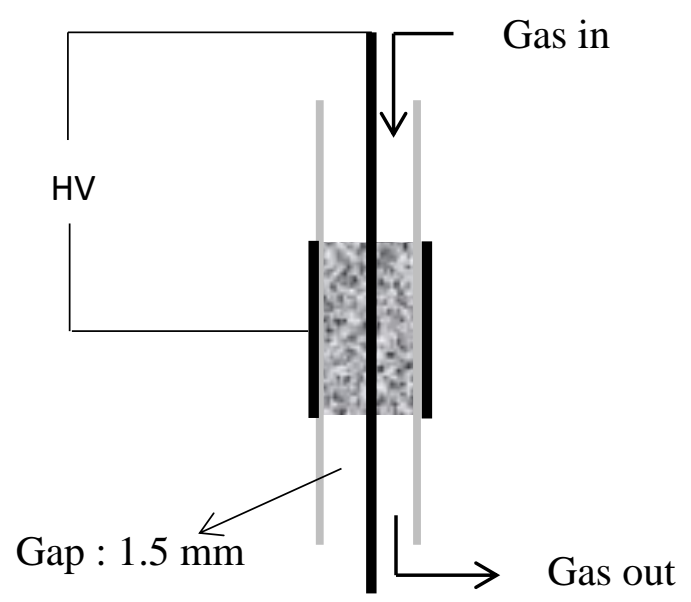


Figure 2: Lissajous figures for $\mathrm{CaO}$, room temperature, grain size: $355-650 \mu \mathrm{m}, \mathrm{P}=8 \mathrm{~W}$, total flow: $40 \mathrm{~mL} / \mathrm{min}, \mathrm{CO}_{2} / \mathrm{CH}_{4}=2$, He: $75 \%$.

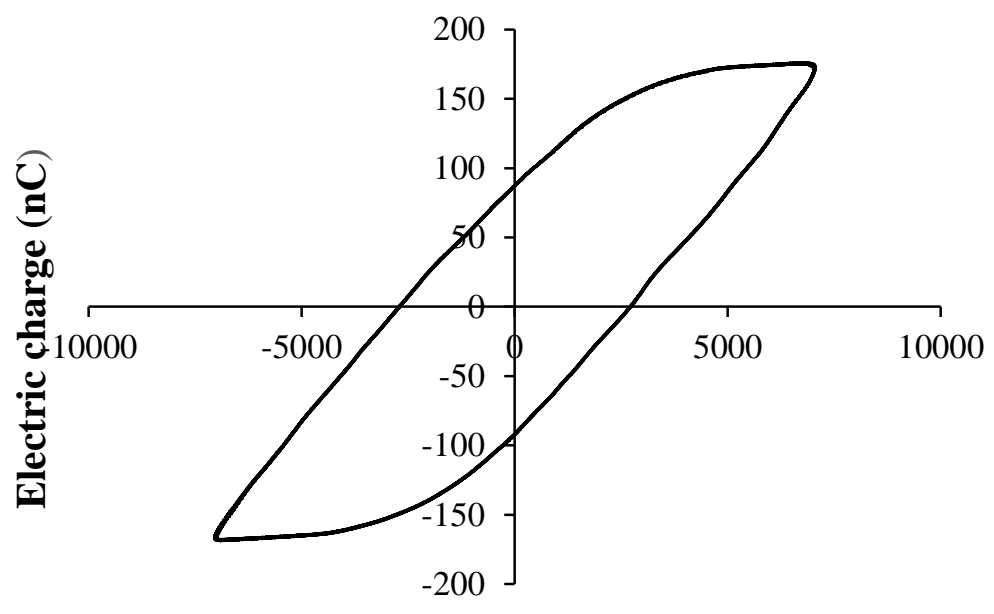

Applied voltage (V) 
Figure 3: Applied voltage and current signals in the presence of $\mathrm{CaO}$, room temperature, grain size: $355-650 \mu \mathrm{m}, \mathrm{P}=8 \mathrm{~W}$, total flow: $40 \mathrm{~mL} / \mathrm{min}, \mathrm{CO}_{2} / \mathrm{CH}_{4}=2$, He: $75 \%$.

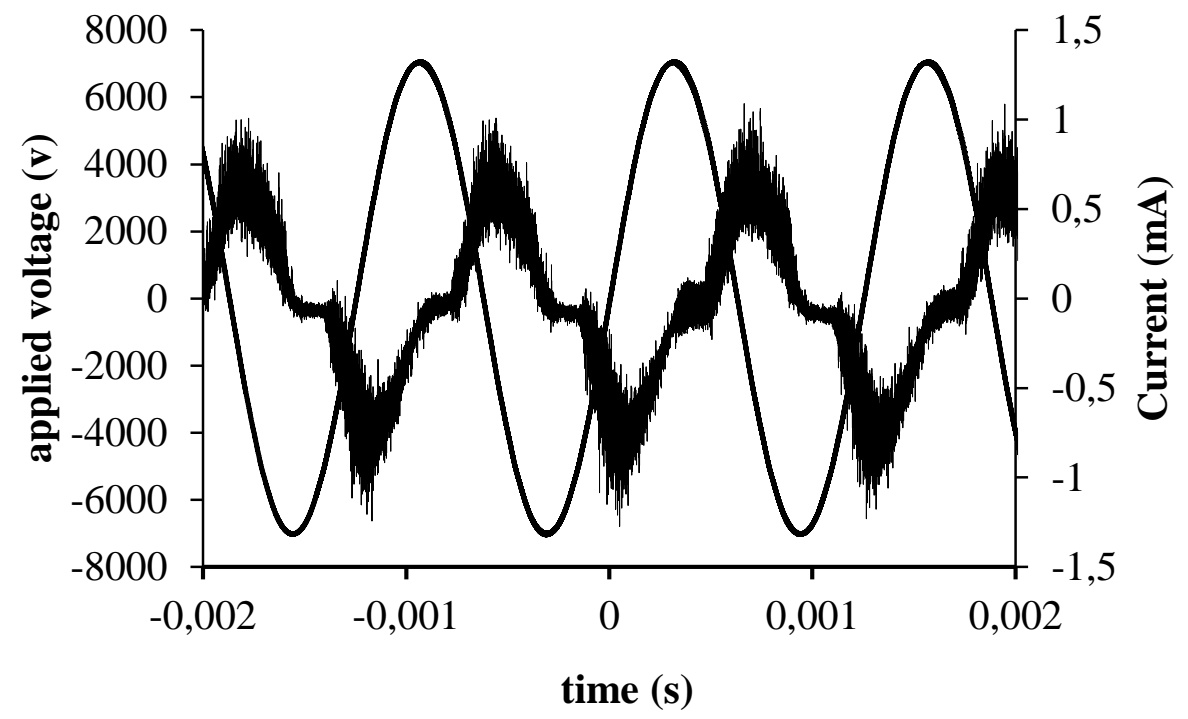


Figure 4: Influence of the ratio $\mathrm{CH}_{4} / \mathrm{CO}_{2}$ for $\mathrm{CH}_{4}$ and $\mathrm{CO}_{2}$ transformation, at room temperature, $\mathrm{T}=100,200$ and $300^{\circ} \mathrm{C}$, Quartz wool in the plasma zone, $\mathrm{P}=8 \mathrm{~W}$, total flow: $40 \mathrm{~mL} / \mathrm{min}$, He: $75 \%$, ratio $\mathrm{CH}_{4} / \mathrm{CO}_{2}$ a) 0.5 ; b) 1.0 ; c) 2.0 ; legend: $+: \mathrm{CH}_{4}$ conversion, $\times \mathrm{CO}_{2}$ conversion

Room T

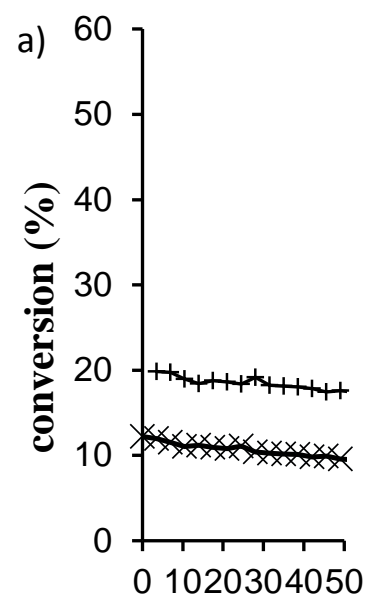

time (min)

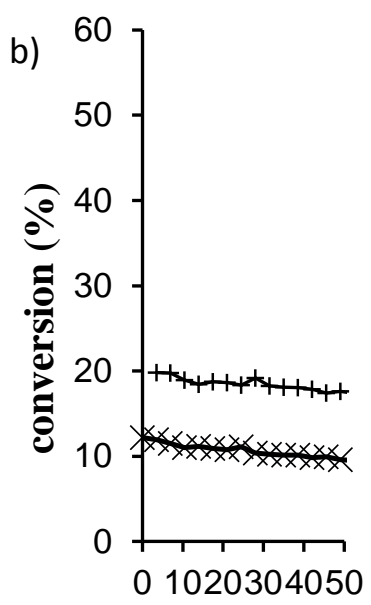

time (min)

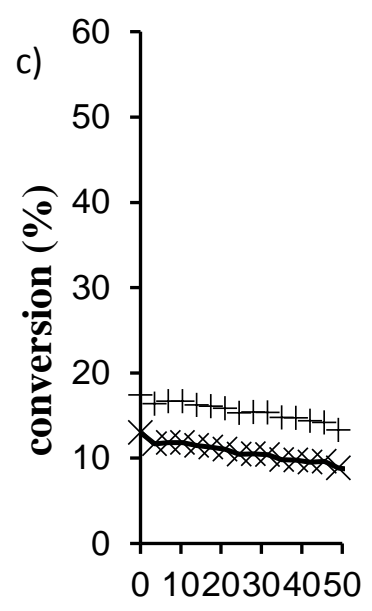

time (min) $100^{\circ} \mathrm{C}$

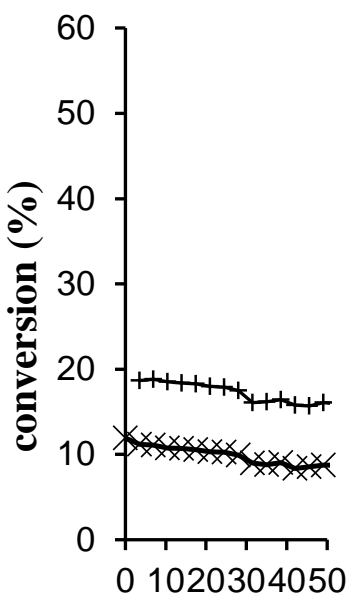

time (min)

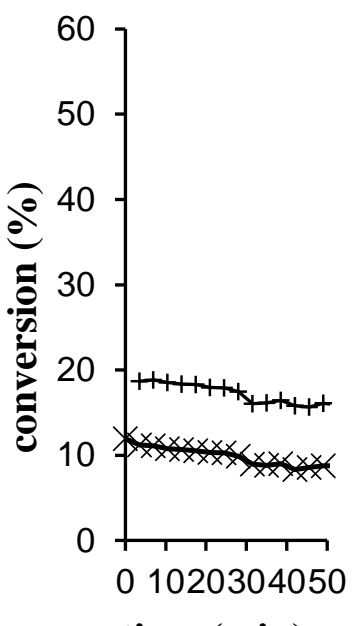

time (min)

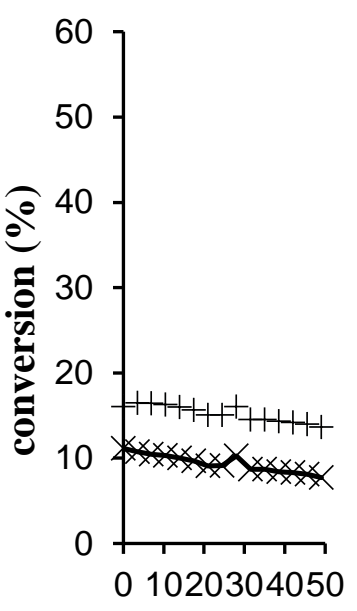

time (min)

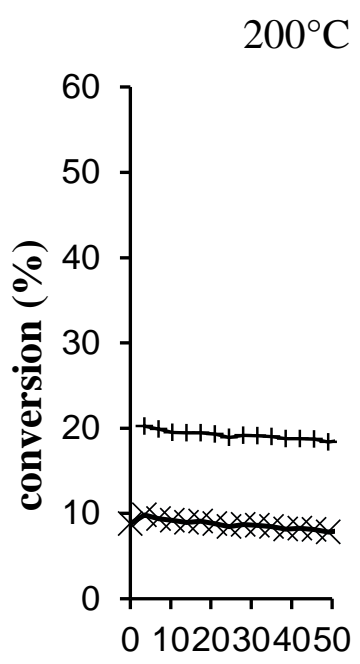

time (min)
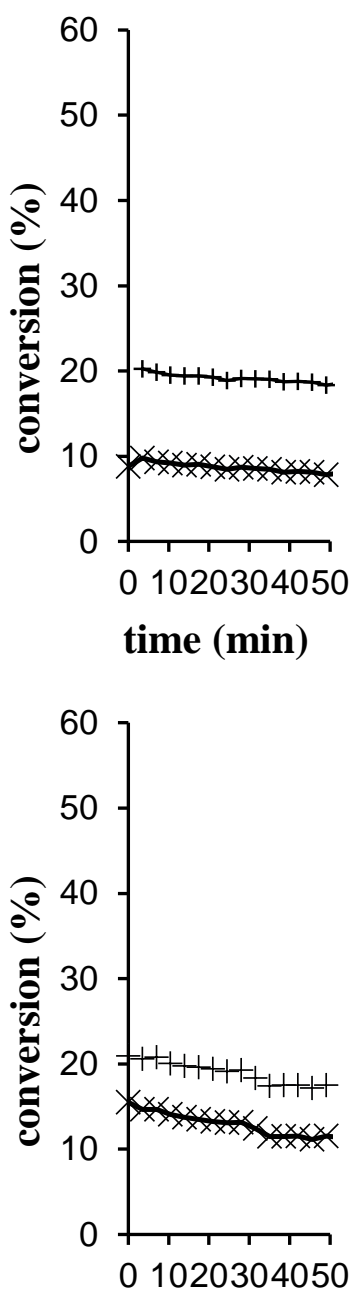

time (min) $300^{\circ} \mathrm{C}$

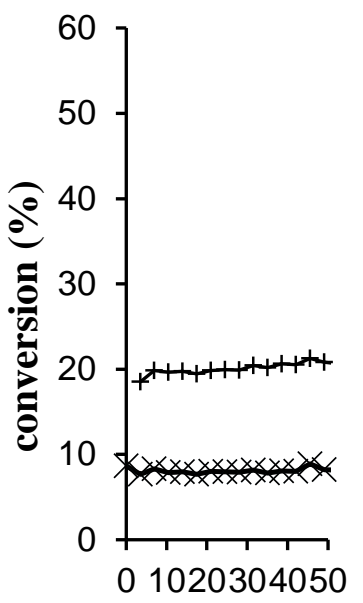

time (min)
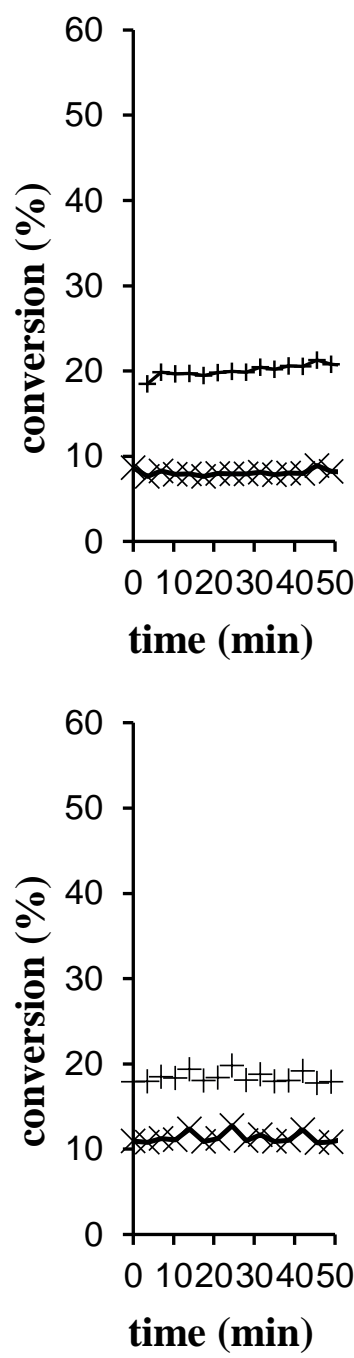
Figure 5: Influence of the grain size on $\mathrm{CH}_{4}$ and $\mathrm{CO}_{2}$ conversion (average value, reaction time: 30 minutes), $\mathrm{CaO}$ calcined at $800^{\circ} \mathrm{C}$ before reaction, $\mathrm{d} 1: 250-355 \mu \mathrm{m}, \mathrm{d} 2: 355-650 \mu \mathrm{m}, \mathrm{d} 3: 650-$ 800, d4: $800-1000 \mu \mathrm{m}, \mathrm{P}=8 \mathrm{~W}$, total flow: $40 \mathrm{~mL} / \mathrm{min}$, He: $75 \%$, ratio $\mathrm{CH}_{4} / \mathrm{CO}_{2}=0.5$

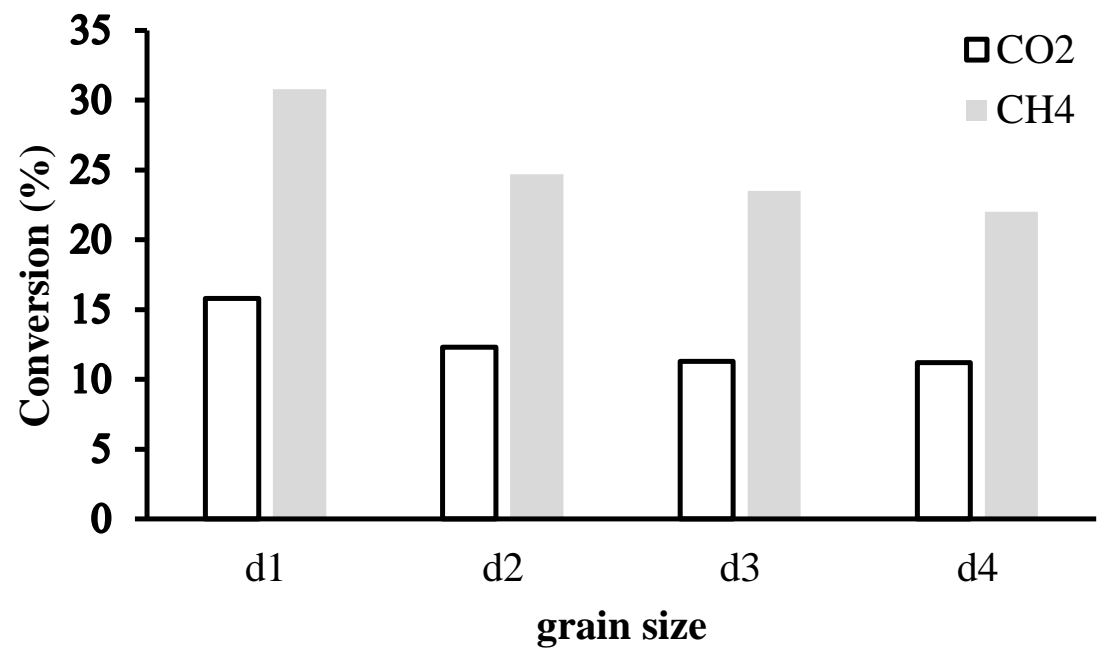


Figure 6: Influence of temperature on $\mathrm{CH}_{4}$ and $\mathrm{CO}_{2}$ conversion, and product selectivity, $\mathrm{CaO}$ calcined at $800^{\circ} \mathrm{C}$ before reaction, grain size: $355-650 \mu \mathrm{m}, \mathrm{P}=8 \mathrm{~W}$, total flow: $40 \mathrm{~mL} / \mathrm{min}$, He: $75 \%$. $\mathrm{CH}_{4} / \mathrm{CO}_{2}=2$, a) $100^{\circ} \mathrm{C}$, b) $200^{\circ} \mathrm{C}$, c) $300^{\circ} \mathrm{C}$
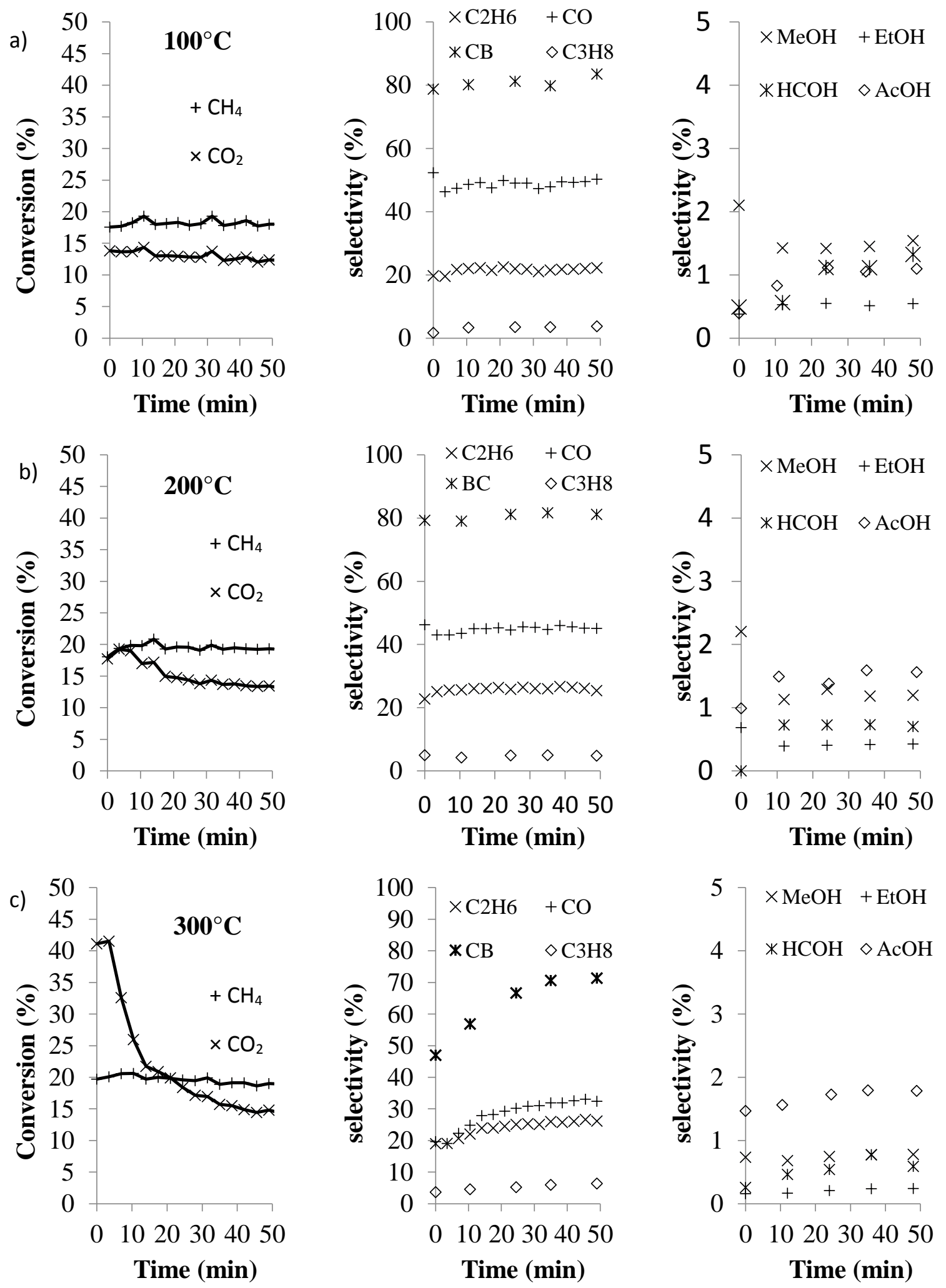
Figure 7: $\mathrm{XRD}$ patterns of $\mathrm{CaO}$ a) after calcination at $800^{\circ} \mathrm{C}$ and after plasma treatment at different temperatures, grain size: $355-650 \mu \mathrm{m}, \mathrm{P}=8 \mathrm{~W}$, total flow: $40 \mathrm{~mL} / \mathrm{min}$, He: $75 \%$. $\mathrm{CH}_{4} / \mathrm{CO}_{2}=2$, b) Room temperature , c) $100^{\circ} \mathrm{C}$, d) $200^{\circ} \mathrm{C}$, e) $300^{\circ} \mathrm{C}$
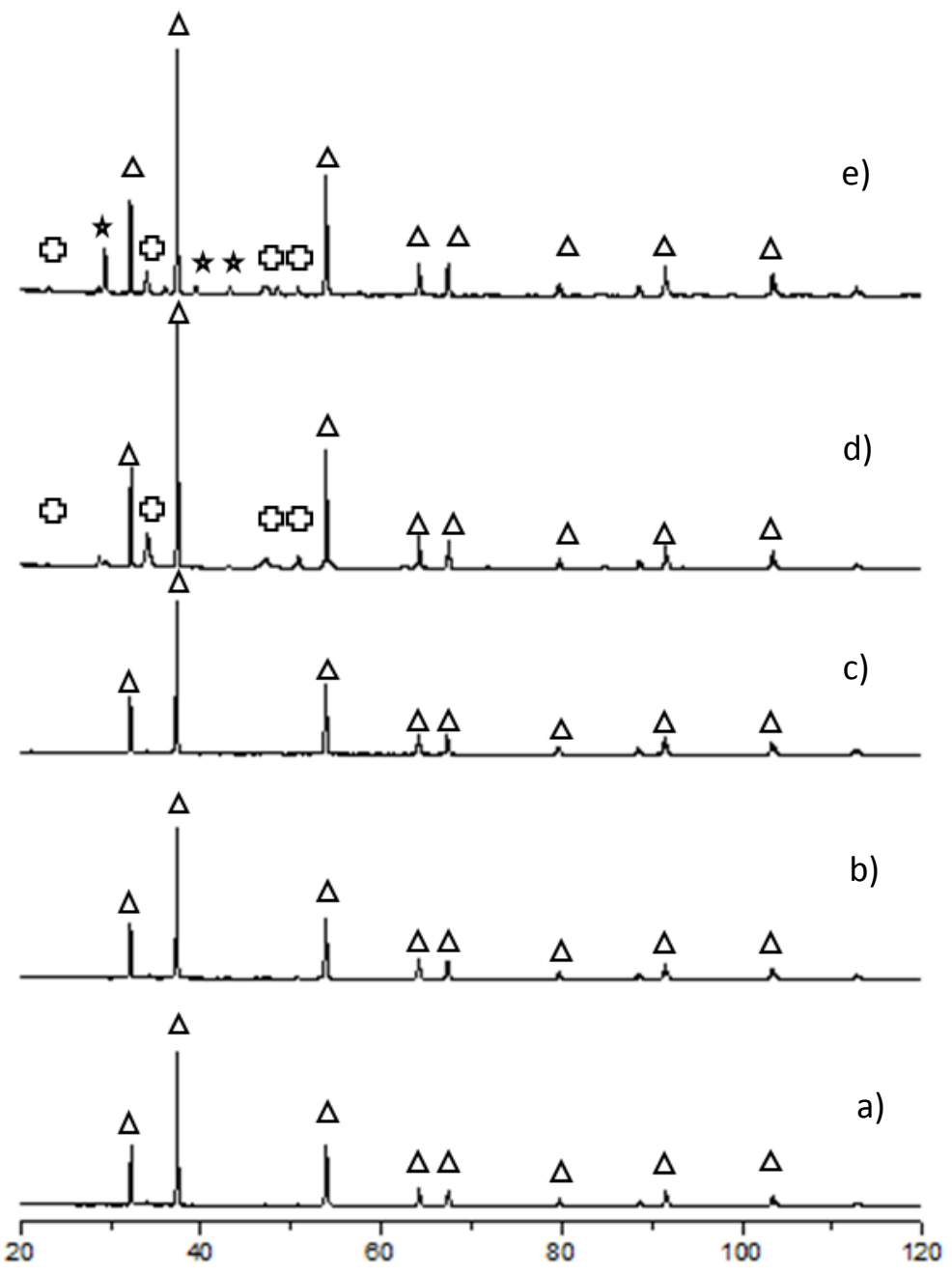

$\triangle \mathrm{CaO}(\mathrm{ICSD} 98-009-0486) \longmapsto \mathrm{Ca}(\mathrm{OH})_{2}(\mathrm{ICSD} 98-007-3467) \star \mathrm{CaCO}_{3}$ (ICSD 98-004-0543) 
Figure 8: Images of the catalyst $(\mathrm{CaO})$ before reaction and after reaction at room temperature, 100, 200 and $300^{\circ} \mathrm{C}$, grain size: $355-650 \mu \mathrm{m}, \mathrm{P}=8 \mathrm{~W}$, total flow: $40 \mathrm{~mL} / \mathrm{min}$, He: $75 \%$. $\mathrm{CH}_{4} / \mathrm{CO}_{2}=2$

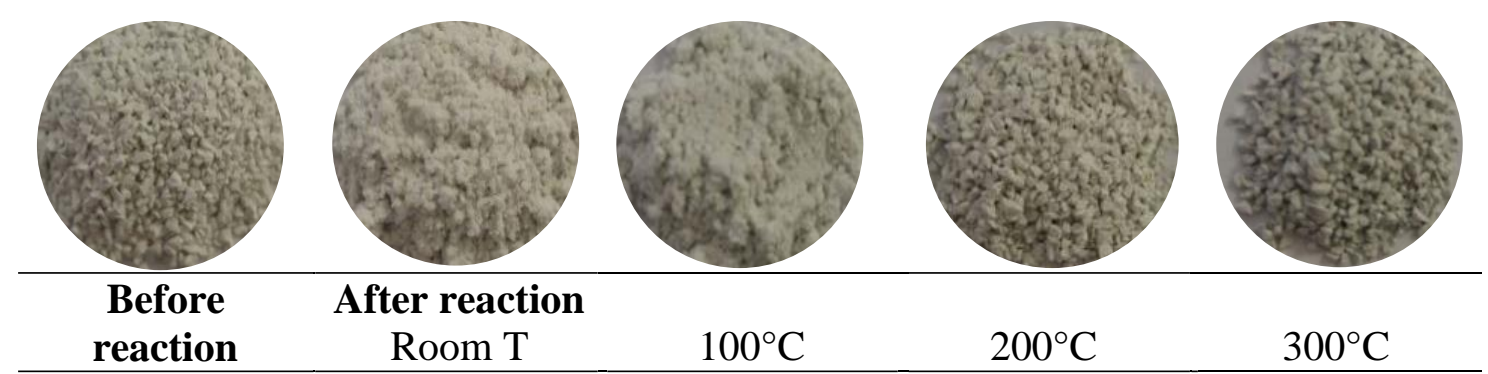


Figure 9: TGA-TDA profiles of $\mathrm{CaO}$ before and after plasma treatment at different temperatures (from 100 to $300^{\circ} \mathrm{C}$ ), grain size: $355-650 \mu \mathrm{m}, \mathrm{P}=8 \mathrm{~W}$, total flow: $40 \mathrm{~mL} / \mathrm{min}$, He: $75 \%$. $\mathrm{CH}_{4} / \mathrm{CO}_{2}=2$
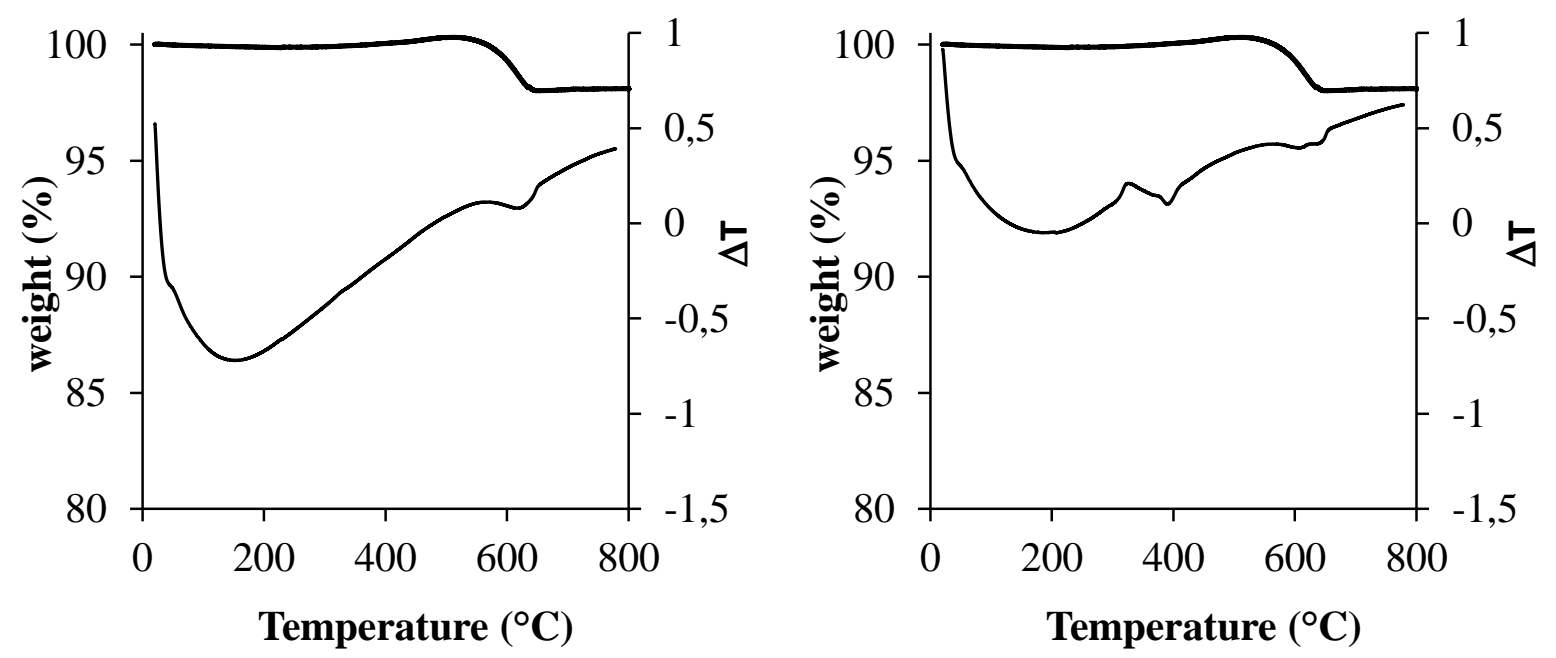

$\mathrm{CaO}$ before reaction

$\mathrm{CaO}$ after plasma reaction at $100^{\circ} \mathrm{C}$

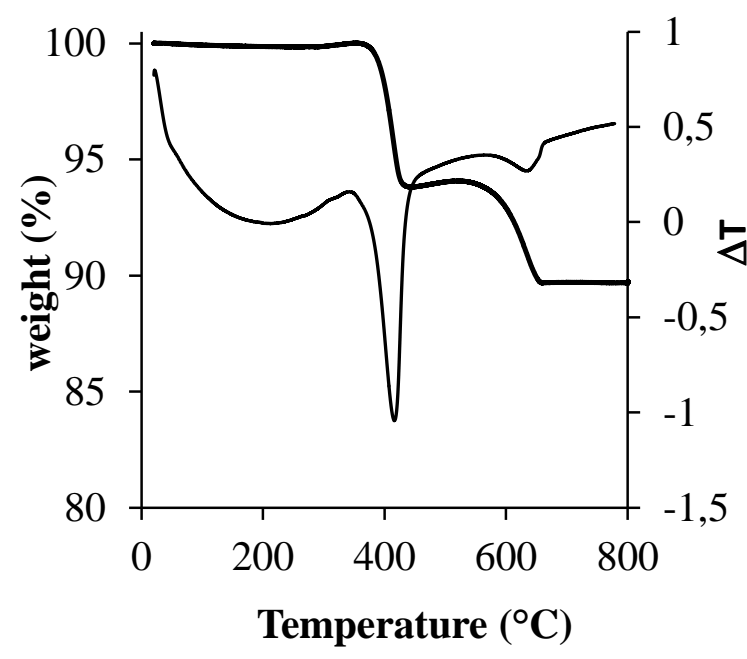

$\mathrm{CaO}$ after plasma reaction at $200^{\circ} \mathrm{C}$

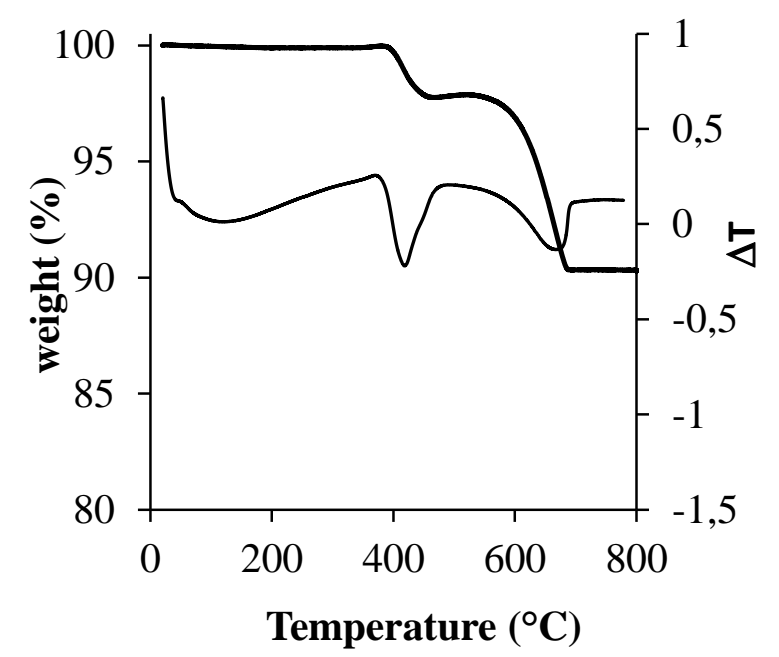

$\mathrm{CaO}$ after plasma reaction at $300^{\circ} \mathrm{C}$ 